\title{
First record of the genus Choledocystus (Trematoda: Plagiorchiidae) for amphibians of the Chacoan region in Argentina
}

\author{
MONIKA INES HAMANN, VIRGINIA LEÓN-RĖGAGNON, MARÍA VIRGINIA \\ FERNÁNDEZ \& CYNTHYA ELIZABETH GONZÁLEZ
}

\begin{abstract}
This is the first record of the trematode Choledocystus incurvatum and Choledocystus elegans in Argentinean amphibians collected in two localities of the Chacoan region. The first trematode species was found infecting the small intestine of Pseudis paradoxa Linnaeus, captured near the city of Corrientes, Corrientes Province; the second species was found infecting the gall-bladder of Lepidobatrachus laevis Budgget, captured in Ingeniero Juárez, Formosa Province. Morphology of these species was studied in detail using light microscopy and scanning electron microscopy (SEM), and compared with previous studies of Brazilian and Venezuelan specimens. Morphological descriptions of these parasites are provided to supplement existing data. Choledocystus incurvatum was characterized using molecular methods by sequencing and analyzing rDNA. Regarding metric characters of $C$. incurvatum, the Argentinean specimens show some differences in body and egg size (some larger than Venezuelan specimens). For C. elegans the specimen shows smaller body size than Brazilian specimens. SEM observations of $C$. incurvatum showed tegument covered with triangular spines and confirmed presence of a sucker-like structure around the genital atrium. The morphological and genetic data on C. incurvatum contribute to a more thorough diagnosis of the genus. Moreover, this report represents the first occurrence of this genus in the Argentine Chacoan region.
\end{abstract}

Key words: Trematoda, Choledocystus, Amphibians, Chacoan region, Argentina.

\section{INTRODUCTION}

Systematic studies provide the foundation for the knowledge of biodiversity that is necessary to tackle a range of increasingly urgent and applied environmental challenges. In particular, the diversity of parasites is characterized by a combination of morphological, physiological, behavioral, life-history, and molecular data. In this context, helminth fauna can be considered as a general model system to elucidate patterns and processes in evolution, ecology and biogeography of fundamental importance across the biosphere (see Hoberg et al. 2015).
Here we provide information about the systematics of trematode parasites that infect amphibians in Argentina; this is a field in which knowledge is partial and there is still much to be done. We report the presence of two species of genus Choledocystus Pereira \& Cuocolo, 1941. This genus was later considered as a synonym of Glypthelmins Stafford, 1905 (see Yamaguti 1971). Prudhoe \& Bray (1982) redefined and presented Choledocystus Pereira \& Cuocolo, 1941 as a valid genus, designating C. elegans (Travassos, 1926) as the type species, and attributing the following main characteristics to the genus: uterus extending laterally beyond the caeca and 
the vitellaria and lack of receptaculum seminis. Razo-Mendivil et al. (2006) also demonstrated the validity of this genus (see Tkach 2008).

Most taxonomic studies of Choledocystus species have been based on morphological studies at light microscope level. In recent years, further morphological features with taxonomically diagnostic significance have been added due to the use of scanning electron microscopy, which enables more detailed observation of external morphological characteristics, and molecular techniques, which enhance the accuracy of species identification. Such studies were applied to the species $C$. hepaticus (Plagiorchiidae), a parasite of Rhinella marinus (Linnaeus) (cited as Bufo marinus) from Mexico (Razo-Mendivil et al. 2006).

In this context, the goal of this paper is to provide additional morphological information and a molecular characterization of previously described species of genus Choledocystus on the basis of specimens recovered from anurans captured in the Chacoan region, Argentina. We add information about the geographical distribution of this genus.

\section{MATERIALS AND METHODS}

A total of 31 adult amphibians were examined in this study. Thirty specimens of Pseudis paradoxa (Linnaeus) (Anura, Hylidae) were collected near the city of Corrientes, Corrientes Province, Argentina ( $27^{\circ} 28^{\prime} \mathrm{S}$; $58^{\circ} 50^{\prime} \mathrm{W}$ ) between October 2008 and April 2011, and one Lepidobatrachus laevis Budgett individual (Anura, Ceratophryidae) was collected in Ingeniero Juárez, Formosa Province, Argentina ( $23^{\circ} 57^{\prime} \mathrm{S}$; $61^{\circ} 44^{\prime} \mathrm{W}$ ) in February 2011. They were transported alive to the laboratory, euthanised in chloroform $\left(\mathrm{CHCl}_{3}\right)$ solution, and dissected following standard protocols (Goater \& Goater 2001). The present study is in accordance with all the regulations and ethical and legal considerations for the capture and use of animals established by the National Council of Scientific Research and Technical of Argentina. Trematodes were observed in vivo, counted, and killed in hot distilled water and preserved in $70 \%$ ethanol. Some specimens were stained with hydrochloric carmine and mounted in Canada balsam. Drawings were made using a camera lucida attached to a Carl Zeiss Jena microscope. Measurements given in the description of each trematode are expressed in micrometers $(\mu \mathrm{m})$, with range followed by the mean \pm SD in parentheses. Infection prevalence and intensity were calculated following Bush et al. (1997). Photographs were taken with a Leica DFC 295 camera mounted on a Leica DM 2500 microscope, Leica Microsystems, Wetzlar, Germany. For examination using scanning electron microscopy (SEM), some specimens were dehydrated through an ethanol series, acetone, and ether. The specimens were goldcoated and examined using a Jeol 5800LV, Jeol, Tokio, Japon. Total DNA was extracted from whole digeneans using standard glass fibre methods (Ivanova et al. 2006). After purification, $2 \mu \mathrm{L}$ of DNA was added to a PCR reaction consisting of $6.25 \mu \mathrm{L}$ of $10 \% \mathrm{D}-(+)$-trehalose dihydrate (Fluka Analytical), $2.00 \mu \mathrm{L}$ of Hyclone ultra-pure water (Thermo Scientific), $1.25 \mu \mathrm{L}$ of $10 \mathrm{X}$ PlatinumTaq buffer (Invitrogen), $0.625 \mu \mathrm{L}$ of $50 \mathrm{mM} \mathrm{MgCl2}$ (Invitrogen), $0.125 \mu \mathrm{L}$ of each primer or primer cocktail, $0.0625 \mu \mathrm{L}$ of $10 \mathrm{mM}$ dNTP (KAPA Biosystems) and $0.060 \mu \mathrm{L}$ of $5 \mathrm{U} / \mu \mathrm{L}$ PlatinumTaq DNA Polymerase (Invitrogen) for a total reaction volume of $12.5 \mu \mathrm{L}$. Amplification and sequencing were performed using the primers JB3 5'-TTT TTT GGG CAT CCT GAG GTT TAT-3' / JB4.5 5'-TAA AGA AAG AAC ATA ATG AAA ATG-3' (Bowles et al. 1995) for the partial COI region. Thermal cycling conditions were $94^{\circ} \mathrm{C}$ for $1 \mathrm{~min}$, five cycles at $94^{\circ} \mathrm{C}$ for $40 \mathrm{~s}, 45^{\circ} \mathrm{C}$ for $40 \mathrm{~s}, 72^{\circ} \mathrm{C}$ for $1 \mathrm{~min}$, followed by 35 cycles at $94^{\circ} \mathrm{C}$ for $40 \mathrm{~s}, 51^{\circ} \mathrm{C}$ 
for $40 \mathrm{~s}, 72{ }^{\circ} \mathrm{C}$ for $1 \mathrm{~min}$ and a final extension at $72{ }^{\circ} \mathrm{C}$ for $5 \mathrm{~min}$. The resulting amplicons were visualized on a 2\% agarose E-gel_ 96 precast gel (Invitrogen) and bidirectionally sequenced. Cycle sequencing was performed using a modified BigDye 3.1 Terminator (Applied Biosystems) protocol (Hajibabaei et al. 2005). Cycle sequencing conditions were $96{ }^{\circ} \mathrm{C}$ for 1 min followed by 35 cycles at $96^{\circ} \mathrm{C}$ for $10 \mathrm{~s}, 55^{\circ} \mathrm{C}$ for $5 \mathrm{~S}, 60^{\circ} \mathrm{C}$ for $2.5 \mathrm{~min}$ and a final extension at $60{ }^{\circ} \mathrm{C}$ for $5 \mathrm{~min}$. Sequencing was performed on an ABI 3730XL capillary sequencer (Applied Biosystems). Traces were assembled and edited using CodonCode v.3.0.1 (CodonCode Corporation, Dedham, Massachusetts). Sequences have been deposited in BOLD (http://www.boldsystems. org) within the project entitled: Platyhelminthes of Amphibians and Reptiles I (PLARI) and in GenBank accession number MH094809. Sequences were aligned with CLUSTAL W (Thompson et al. 1994) using sequences from GenBank of closely related taxa based on RazoMendivil et al. (2006), resulting in an alignment of 360 positions. Tree was constructed in PAUP 4.0a (build 161) (Swofford 2002). Unweighted parsimony analysis using exhaustive search was performed considering character states unordered and gaps as missing data. Specimens were deposited in the Helminthological Collection of Centro de Ecología Aplicada del Litoral (CECOAL), Corrientes city, Corrientes Province, Argentina [accession numbers CECOAL, 11022404, Choledocystus incurvatum; 11020901, Choledocystus elegans]. A sample of toad was deposited in the Herpetology Collection of CECOAL-CONICET, with accession number 5143, Pseudis paradoxa; 5141, Lepidobatrachus laevis.

\section{RESULTS}

One hundred eighteen specimens of the trematode choledocystus incurvatum
(Trematoda: Plagiorchiidae) were found in $P$. paradoxa (prevalence of infection: $83 \%, 25$ of 30 amphibians infected; intensity: 118; mean intensity $4.7 \pm 9.1$; min. - max. 1-47. One specimen of $C$. elegans was found in L. laevis (prevalence of infection: $100 \%, 1$ of 1 amphibian infected).

Choledocystus incurvatum (Nasir, 1966) Sullivan, 1976 (Figure 1a-e, Figure 2a-f)

Host: P. paradoxa (Hylidae)

Site of infection: small intestine

Hosts and localities: Pseudis paradoxa from Valle de la Pascua, Guárico, Venezuela (Nasir 1966) (Type host and type locality), P. paradoxa from Los Guaraúnos, Sucre, Venezuela (Sullivan 1976)

Type host and type locality: P. paradoxa, Guárico, Venezuela (Nasir 1966)

Diagnosis (based on 11 specimens). Body rounded-oval to fusiform (Figures 1a, b). Tegument covered with triangular spines (Figure 2a) distributed more densely in anterior region of body (Figures 2a, b). Spines decreasing in number from post-acetabular region to posterior end of body (Figures 2c, f). Oral sucker subterminal, larger than or equal to ventral sucker. Ventral sucker closely preequatorial, with spines and papillae (Figure 2e). Prepharynx indistinct. Pharynx well developed, with peripharyngeal glands. Oesophagus short. Intestinal caeca extending almost to posterior end. Testes entire, approximately rounded, arranged obliquely in middle of body. Cirrus-sac sacculate, relatively small, arcuate; contains coiled seminal vesicle, pars prostatica and unarmed cirrus (Figure 1c). Genital pore submedian, immediately preacetabular and with a small sucker-like structure surrounding its opening (Figure $2 \mathrm{~d}$ ). Ovary submedian, in ventral sucker region, sometimes overlapped by ventral sucker. Seminal receptacle absent. Uterus extending into extracecal area. Metraterm 
opening into the common genital pore. Eggs operculate (Figure 1e). Vitelline follicles lateral to caeca, extracecal, commencing at approx. level of posterior intestinal bifurcation and extending to beginning of last third of body. Excretory bladder Y-shaped, with short limbs (Figure 1d), that opens to the outside through a pore (Figure 2f). Measurements of specimens are given in Table I.

Remarks: This species can be distinguished by the uterine loops spread into the extracecal region, the Y-shaped excretory bladder, and the vitelline glands formed by follicles distributed extracaecally, mostly extending from the postcecal bifurcation region to beyond posterior testis. With respect to the original description of this species by Nasir (1966) in P. paradoxa the difference with the specimens studied here are the possession of a longitudinal depression in the preacetabular region, and the distribution of vitelline follicles, which extend to cecal ends. Sullivan (1976) redescribed this species in the same host from Venezuela, and transferred it to genus Choledocystus. This second description is similar to the present one. Furthermore, neither includes the ventral longitudinal depression mentioned in the original description, which, according to Sullivan, may be a fixation artifact. The greatest difference between the previous studies and this work is that the specimens reported here are larger (maximum length: 4750; maximum width: 1550). The morphological variation of body size could be related mainly to the developmental stage of the specimens, and by the number of parasites at the infrapopulation level or by the use of different fixing techniques. SEM observations showed the tegument covered with triangular spines that do not disappear in the posterior half of body, and confirmed the presence of a sucker-like structure surrounding its opening, but did not show several small papillae that give the appearance of a sucker,

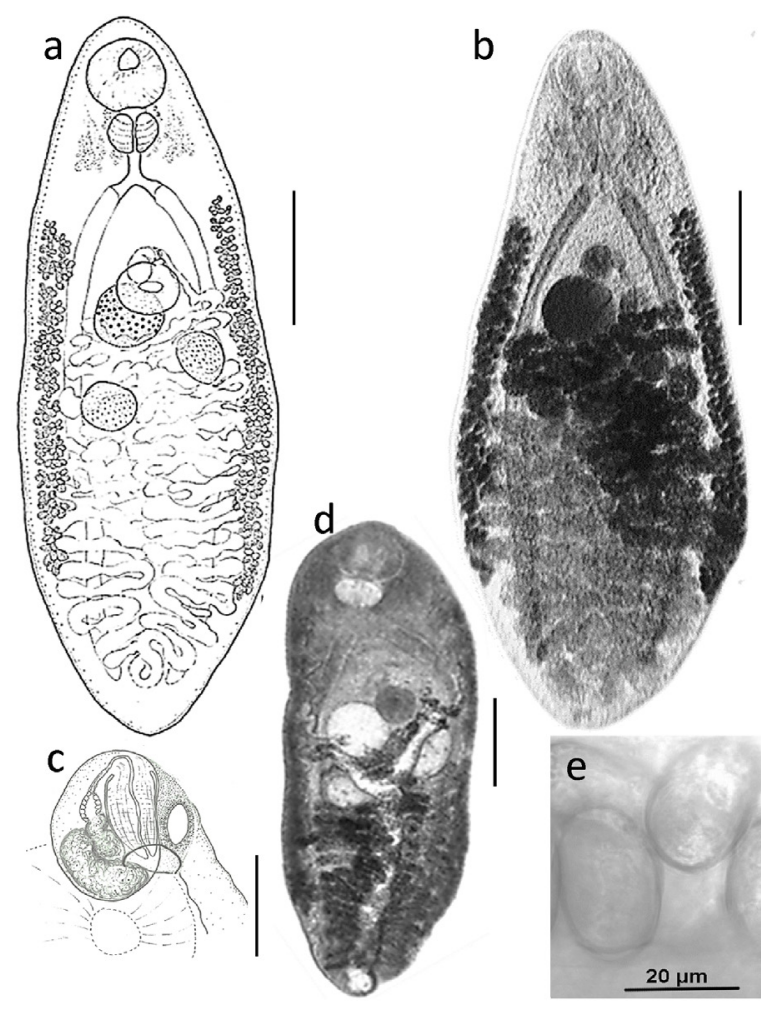

Figure 1. Choledocystus incurvatum $(\mathbf{a}, \mathbf{b})$ body in ventral view, (c) detail of terminal genitalia, (d) body in ventral view showing excretory vesicle, (e) detail of eggs in the uterus. Scale bars: a, b, d = 500 $\mu \mathrm{m} ; \mathrm{c}=100$ $\mu \mathrm{m}$

and the genital atrium was not separated from the ventral sucker, i.e. not at level of the cecal bifurcation. These last two morphological characters differ from those cited for the genus Choledocystus (see Razo-Mendivil et al. 2006, Tkach 2008). Thus, these morphological data contribute to a more accurate diagnosis of this genus, which was until now unrecorded in the Chacoan region. It should be also noted that the present material was collected from the same host, P. paradoxa, as the original specimens of Nasir (1966) and those of Sullivan (1976), and as they are also similar in morphology and location within the host, our material could be considered to be conspecific with the specimens from Venezuela. 


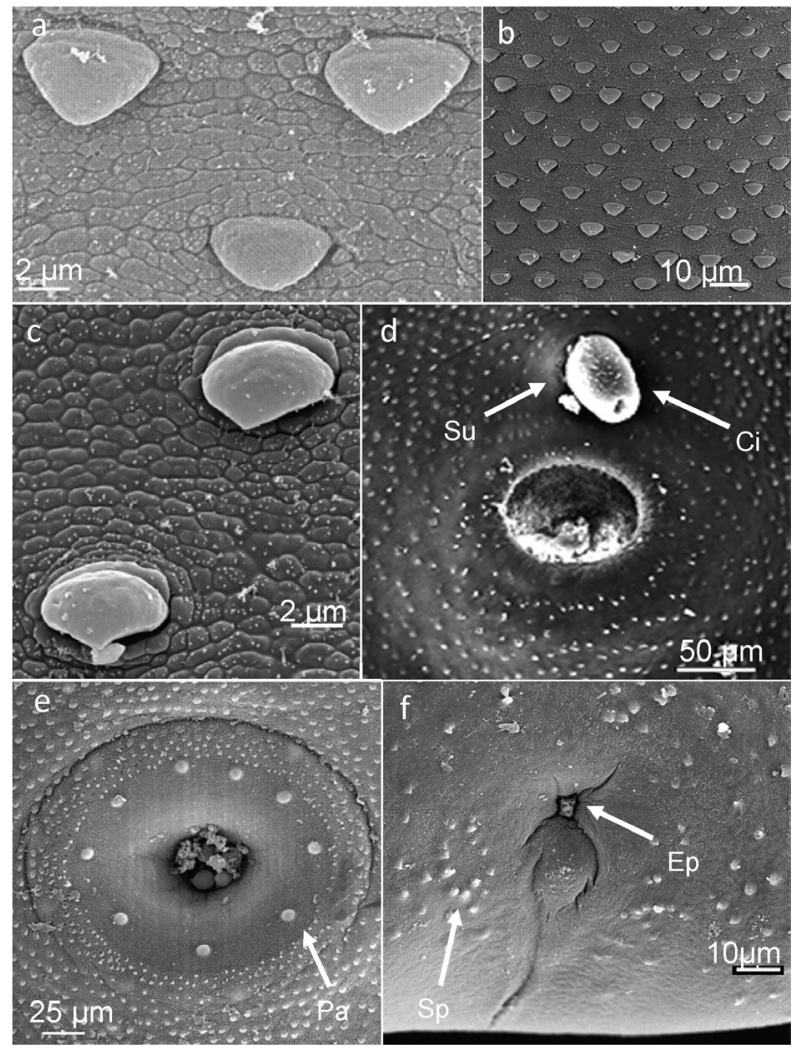

Figure 2. Scanning electron micrographs of Choledocystus incurvatum (a) tegumental spination of anterior ventral body region, (b) arrangement of spines on anterior region of ventral sucker, (c) tegumental spination of posterior ventral body region, (d) genital pore showing sucker surrounding its opening and everted cirrus, (e) detail of the ventral sucker with spines and papillae, (f) posterior end of body showing spines and excretory pore. Abbreviations: $\mathrm{Pa}$, papillae; $\mathrm{Sp}$, spines; Ep, excretory pore; Ci, cirrus; Su, genital sucker.

The sequence of C. incurvatum shows $17 \%$ of divergence compared with the sequences of C. hepaticus and more than 20\% compared with sequences of members of other genera, supporting the inclusion of $C$. incurvatum in the genus Choledocystus (Figure 3).

Choledocystus elegans (Travassos, 1926) Pereira \& Cuocolo, 1941 (Figure 4a-e)

Host: Lepidobatrachus laevis (Ceratophryidae) Site of infection: gall-bladder
Hosts and localities: Leptodactylus latrans (Steffen, 1815) (= Leptodactylus ocellatus) from São Paulo, Brazil (Travassos 1926) (Type host and type locality), L. latrans and Rhinella marina (Linnaeus, 1758) (= Bufo marinus) from the same locality (Ruiz 1949, Pereira \& Cuocolo 1941), Leptodactylus labyrinthicus (Spix, 1824) (= Leptodactylus pentadactylus labyrinthicus), Leptodactylus latrans (Steffen, 1815) (= Leptodactylus ocellatus) and Rhinella icterica (Wied-Neuwied, 1821) (= Bufo marinus bimaculatus) from Pernambuco and Curitiba, Brazil (Dobbin 1957), L. latrans from Riacho Cuñá Pirú, Cainguás, Misiones, Argentina (see Check List Lunaschi \& Drago 2010).

Diagnosis (based on one specimen). Body rounded-oval to fusiform (Figures $4 \mathrm{a}$, b). Tegument covered with triangular spines (Figures $4 \mathrm{~d}, \mathrm{e}$ ) extending from region of oral sucker to posterior end of body. Oral sucker subterminal, larger than ventral sucker. Ventral sucker closely pre-equatorial. Prepharynx indistinct. Pharynx well developed. Oesophagus short. Intestinal caeca extend to vicinity of posterior extremity. Testes entire, more or less rounded, arranged symmetrically or somewhat obliquely in middle of body. Cirrussac relatively large, arcuate; contains bipartite seminal vesicle, well-developed pars prostatica and unarmed cirrus. Genital pore submedian, close to level of intestinal caecal bifurcation, with a small sucker-like structure surrounding its opening. Ovary submedian, immediately posterior to ventral sucker. Uterus extending into extracecal area. Metraterm formed by unicellular glands, approximately as long as cirrus-sac. Eggs operculate (Figure 4c). Seminal receptacle absent. Vitelline follicles lateral to intestinal caeca and partly overlapping them, extending from intestinal bifurcation region to level of posterior testes region. Excretory bladder approximately Y-shaped, with very short 
Table I. Comparative morphometrics of Choledocystus incurvatum found in Pseudis paradoxa from the Chacoan region, Argentina.

\begin{tabular}{|c|c|c|c|}
\hline References & Nasir (1966) & Sullivan (1976) & Present study \\
\hline Locality & Venezuela & Venezuela & Argentina \\
\hline Body length & $1728-2196$ & $1270-3500(2470)$ & $2150-4750(3121 \pm 816)$ \\
\hline Maximum width & $540-612$ & $580-1330(910)$ & $763-1550(1072 \pm 251)$ \\
\hline Pharynx l / w & $81-131$ & $110-200(180) / 100-220(180)$ & $120-210(163 \pm 34) / 135-280(187 \pm 51)$ \\
\hline Oral sucker l / w & $193-206$ & $170-330(250) / 180-350(260)$ & $175-390(272 \pm 63) / 200-370(253 \pm 47)$ \\
\hline Ventral sucker I / w & $131-165$ & $110-230(180) / 110-250(200)$ & $170-270(219 \pm 36) / 165-270(228 \pm 34)$ \\
\hline Relation suckers l/w & 1:0.68-1:0.80 & $1: 0.73 \pm 0.05$ & $1: 0.81 \pm 0.09 / 1: 0.88 \pm 0.08$ \\
\hline Anterior testis I / w & $75-100 / 50-87$ & $70-250(160) / 80-250(180)$ & $125-300(212 \pm 49) / 125-300(214 \pm 45)$ \\
\hline Posterior testis I / w & $87-100 / 62-87$ & $80-220(170) / 80310(200)$ & $145-280(218 \pm 45) / 150-300(226 \pm 45)$ \\
\hline Ovary l / w & $100-131$ & --- & $170-320(238 \pm 46) / 175-350(253 \pm 54)$ \\
\hline Cirrus-sac l/w & $150-175 / 62-75$ & $70-290(210) / 30-120(90)$ & $145-253(196 \pm 45) / 78-125(100 \pm 17)$ \\
\hline Eggs l / w & $25-33 / 14-16$ & $29-34(31) / 12-15(14)$ & $30-38(35 \pm 2) / 14-18(16 \pm 1)$ \\
\hline
\end{tabular}

Abbreviations: I length, $w$ = width.

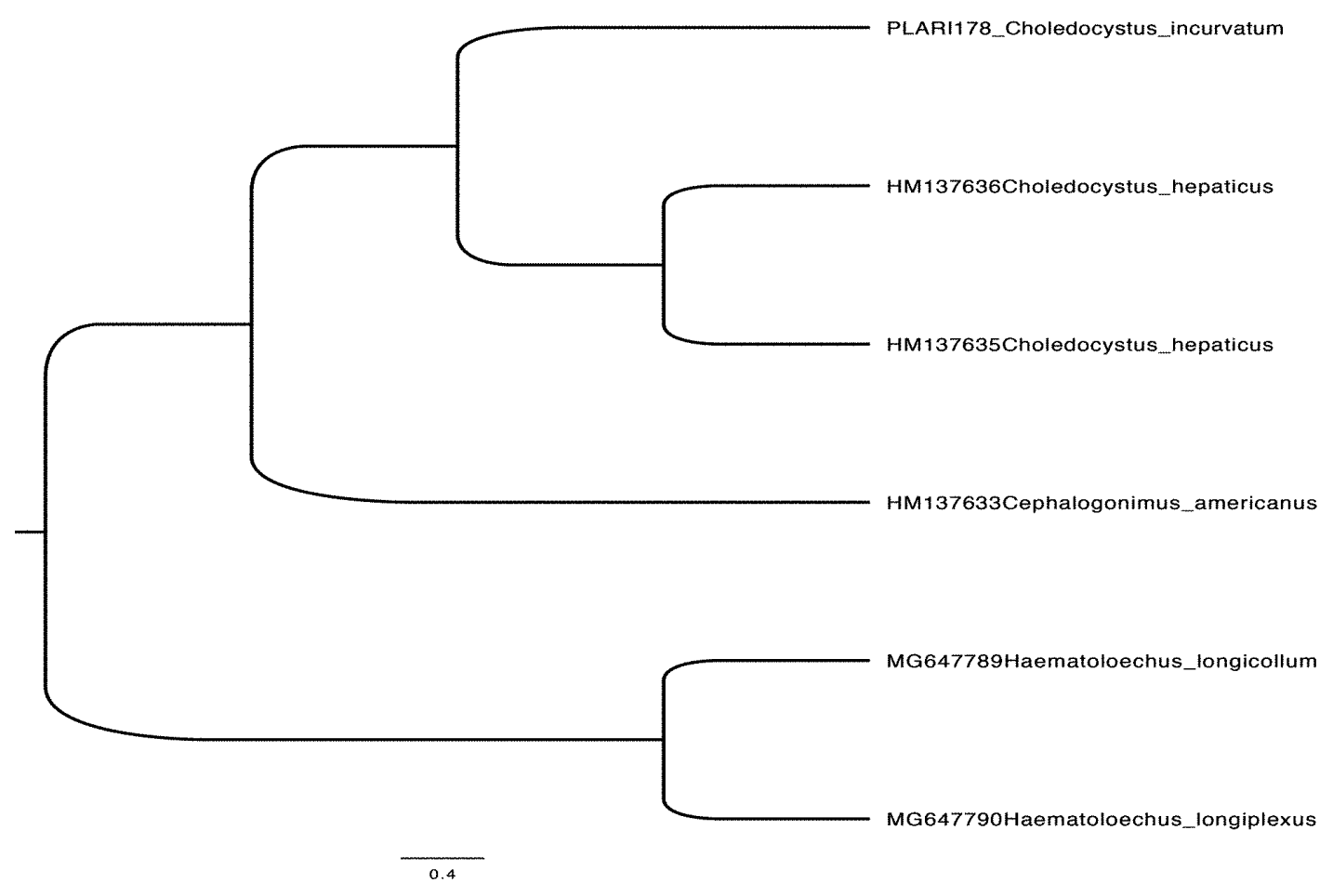

Figure 3. Most parsimonious phylogenetic tree (consistency index $=0.9$ ) of partial COI sequences of Choledocystus incurvatum and close relatives obtained from GenBank. 
limbs. Measurements of specimens collected from each species of amphibian host are given in Table II.

Remarks: This species can be distinguished by the uterine loops which extend into extracecal region, the Y-shaped excretory bladder and the vitelline glands formed by follicles distributed lateral to the intestinal caeca and partly overlapping them from the region of the cecal bifurcation to the beginning of the last third of the body. These morphological data were confirmed by Travassos (1926) for the type species (C. elegans) found in the small intestine of the host Leptodactylus latrans collected in São Paulo, Brazil. Similarly, these morphological features have also been mentioned in studies by Pereira \& Cuocolo (1941) in the host L. latrans and by Ruiz (1949) in Rhinella marina, all from the same locality. In addition, Dobbin (1957) redescribed C. elegans from the gallbladder of Leptodactylus labyrinthicus, Leptodactylus latrans and Rhinella icterica from the localities of Pernambuco and Curitiba, Brazil. Our C. elegans specimen closely resembles the specimens described from Brazil, but the latter were longer than the specimen described here. With respect to the vitelline follicles, they are slightly shorter than in the Brazilian specimens. Additionally, this species has also been cited in L. latrans of Misiones Province, Argentina (Lunaschi \& Drago 2010). The present study is the first to identify the parasite $C$. elegans in the host L. laevis.

\section{DISCUSSION}

The life cycles of both Choledocystus species have not yet been studied, but they may resemble those of other Plagiorchiinae species (Smyth \& Smyth 1980). These digeneans have a two-host life cycle involving a snail as intermediate host and amphibians as definitive hosts. The xiphidiocercaria emerge from the snail and come into contact with a frog or its tadpole. In these hosts an abbreviated life cycle, i.e., a short cycle with or without development of metacercariae, was observed (Grabda-Kazubska 1976, Smyth \& Smyth 1980).

Table II. Comparative morphometrics of Choledocystus elegans found in Lepidobatrachus laevis from the Chacoan region, Argentina.

\begin{tabular}{|c|c|c|c|}
\hline References & Travassos (1926) & Dobbin JE Jr (1957) & Present study \\
\hline Locality & Brazil & Brazil & Argentina \\
\hline Body length & $3000-3200$ & $2150-3526$ & 1475 \\
\hline Maximum width & $1400-1700$ & $1290-1720$ & 625 \\
\hline Pharynx l / w & $170-250$ & $122-217 / 165-226$ & $110 / 152$ \\
\hline Oral sucker I / w & $250-370$ & $245-365 / 270-374$ & $150 / 175$ \\
\hline Ventral sucker I / w & $250-270$ & 217-357/217-339 & $140 / 130$ \\
\hline Relation suckers I/w & 1:1-1:0.72 & $1: 1$ & 1:1/1: 0.93 \\
\hline Anterior testis I / w & $350 / 370$ & $217-400 / 261-470$ & $115 / 175$ \\
\hline Posterior testis I / w & $450 / 420$ & $252-409 / 278-522$ & $150 / 200$ \\
\hline Ovary l / w & $300-420$ & $165-304 / 191-322$ & $125 / 130$ \\
\hline Cirrus-sac l/w & $700-820 / 170-200$ & $349-747 / 149-249$ & $300 / 90$ \\
\hline Eggs l / w & $33-38 / 12-20$ & $29-38 / 13-17$ & $24-35(28 \pm 4) / 13-17(15 \pm 2)$ \\
\hline
\end{tabular}

Abbreviations: $\mathrm{l}$ = length, $\mathbf{w}=$ width. 
a
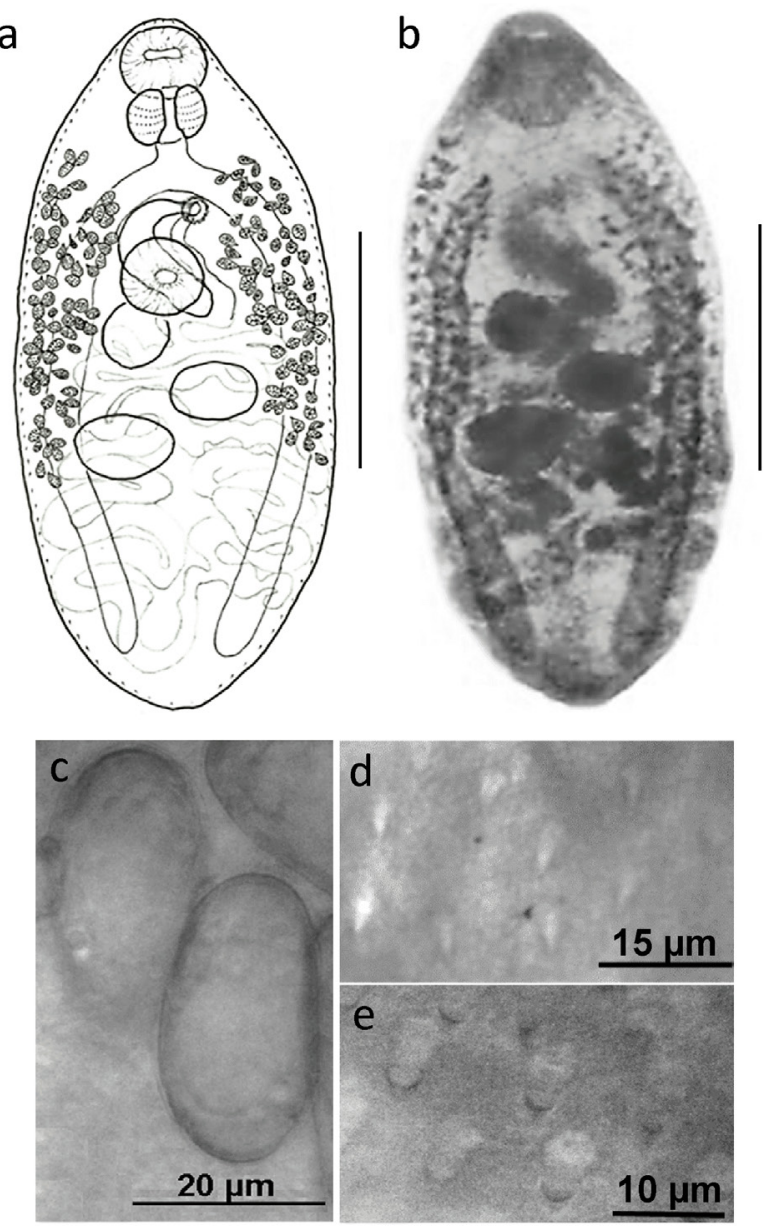

Figure 4. Choledocystus elegans $(a, b)$ body in ventral view, (c) detail of eggs in the uterus, (d) tegumental spination of anterior ventral body region, (e) tegumental spination of posterior ventral body region. Scale bars: $a, b=500 \mu \mathrm{m}$.

The trematode species described here are the first record of genus Choledocystus in the Chacoan region. Therefore, the finding of $C$. incurvatum and C. elegans in amphibians of Argentina increases the geographical range of these species in South America. Both species show wide geographical distribution in South America, ranging from Brazil (C. elegans) and Venezuela (C. incurvatum) to Argentina. We consider that the wide distribution of these Choledocystus species is due to the distribution of their original amphibian hosts in some areas of South America. Furthermore, the species C. elegans exhibits low host-specificity and has been able to colonize three different host groups in Brazil (see Dobbin 1957), while C. incurvatum is a specialist species restricted to a single host species: P. paradoxa collected in Venezuela (Nasir 1966, Sullivan 1976) and in Argentina (the present study).

As a result of the present study, the generic diagnosis of Choledocystys is expanded with the following traits: cirrus-sac elongate to sacculate, arcuate; contains bipartite or coiled seminal vesicle, genital pore submedian, near level of intestinal caecal bifurcation or immediately preacetabular, and presence of a small suckerlike structure surrounding its opening. Adult parasites commonly occur in the hepatic system and intestine of amphibians (see Tkach 2008).

As there are no previous studies of the genetic characteristics of $C$. incurvatum, the molecular data presented here represent an important advance for the molecular identification and differentiation of Choledocystus spp. In addition, the molecular data for C. incurvatum may contribute to future studies on population genetics and phylogenetic of this species. Finally, this study also extends the known geographic distribution of both parasitic species and contributes to the knowledge of the helminth fauna of amphibians from Chacoan environments.

\section{Acknowledgments}

We thank Dr. Bray, H.D of the Secretary of Natural Resources and Environmental Quality of the Production and Environment Ministry of Formosa Province, and the office of the Secretary of Natural Resources of Corrientes Province, Argentina to authorize the capture of the toads for this research. Financial support was provided by CONICET of Argentina, through grant PIP 0111 to M. I. Hamann. 


\section{REFERENCES}

BOWLES J, BLAIR D \& MCMANUS DP. 1995. A molecular phylogeny of the genus Echinococcus. Parasitology 110: 317-328.

BUSH AO, LAFFERTY K, LOTZ JM \& SHOSTAK AW. 1997. Parasitology meets ecology on its own terms: Margolis et al. revisited. J Parasitol 83: 575-583.

DOBBIN JE JR. 1957. Fauna helmintológica de batráquios de Pernambuco, Brasil. I. Trematoda. An Soc Biol Pernambuco 15: 23-61.

GOATER T \& GOATER CP. 2001. Ecological Monitoring and Assessment Network (EMAN) Protocols for Measuring Biodiversity: Parasites of Amphibians and Reptiles. http://www.eman-rese.ca/eman/ecotools/protocols/ terrestrial/herp parasites/intro.html.

GRABDA-KAZUBSKA B. 1976. Abbreviation of the life cycles of plagiorchid trematodes: general remarks. Acta Parasitol Polonica 24: 125-141.

HAJIBABAEI M, DEWAARD JR, IVANOVA NV, RATNASINGHAM S, DOOH RT, KIRK SL, MACKIE PM \& HEBERT PD. 2005. Critical factors for assembling a high volume of DNA barcodes. Philos Trans Royal Soc B-Biol Sci 360: 1959-1967.

HOBERG EP, AGOSTA SJ, BOEGER WA \& BROOKS DR. 2015. An Integrated parasitology: Revealing the elephant through tradition and invention. Trends Parasitol 31: 128-133.

IVANOVA NV, DEWAARD JR \& HEBERT PDN. 2006. An inexpensive, automation-friendly protocol for recovering high-quality DNA. Mol Ecol Notes 6: 998-1002.

LUNASCHI LI \& DRAGO FB. 2010. Platyhelminthes, Trematoda, Digenea Carus, 1863: Distribution extension in Argentina and new Anura and Ophidia hosts. Check List 6: 447-450.

NASIR P. 1966. Two new species of digenetic trematodes from Venezuelan amphibians. Proc Helminthol Soc Wash 33: $166-170$.

PEREIRA C \& CUOCOLO R. 1941. Proceso papilomatoso das vías biliares de Leptodactylus ocellatus determinado por Choledocystus eucharis. Arq Inst Biol 12: 311-324.

PRUDHOE S \& BRAY RA. 1982. Platyhelminth parasites of the amphibian. British Museum (Natural History), London: Oxford University Press, 217 p.

RAZO-MENDIVIL UJ, LEÓN-REGAGNON V \& PÉREZ-PONCE DE LEÓN G. 2006. Monophyly and systematic position of Glypthelmins (Digenea), based on partial IsrDNA sequences and morphological evidence. Org Divers Evol 6: 308-320.
RUIZ J. 1949. Consideracões sôbre o gênero "Choledocystus" Pereira y Cuocolo, 1941 (Trematoda, Plagiorchiidae). Rev Bras Biol 9: 167-174.

SMYTH JP \& SMYTH MM. 1980. Frogs as host-parasite systems I. An introduction to parasitology through the parasites of Rana temporaria, R. esculenta and R. pipiens. London: Macmillan Press, $112 \mathrm{p}$.

SULLIVAN J. 1976. Redescription of Choledocystus incurvatum (Nasir, 1966) N. Comb., (Digenea: Plagiorchiidae), a parasite of Pseudis paradoxa (L.) in Venezuela. Riv Parassitol 37: 241-245.

SWOFFORD DL. 2002. PAUP*. Phylogenetic Analysis Using Parsimony (*and Other Methods). Version 4. Sunderland, Massachusetts: Sinauer Associates, 142 p.

THOMPSON JD, HIGGINS DG \& GIBSON TJ. 1994. CLUSTAL W: improving the sensitivity of progressive multiple sequence alignment through sequence weighting, position-specific gap penalties and weight matrix choice. Nucleic Acids Res 22: 4673-4680.

TKACH VV. 2008. Familiy Plagiorchiidae Lühe, 1901. In: Bray RA et al. (Eds), Keys to the trematode: CABI Publishing and The Natural History Museum, London, UK, p. 295-325.

TRAVASSOS 1926. Trematodos novos. V. Bol Biol 1: 16-19.

YAMAGUTI S. 1971. Synopsis of the digenetic trematodes of vertebrates, Vol. 1. Tokyo: Keigaku Publishing Company, 1074 p.

\begin{abstract}
How to cite
HAMANN MI, LEÓN-RÈGAGNON V, FERNÁNDEZ MV \& GONZÁLEZ CE. 2020. First record of the genus Choledocystus (Trematoda: Plagiorchiidae) for amphibians of the Chacoan region in Argentina. An Acad Bras Cienc 92: e20180384. DOI 10.1590/0001-3765202020180384.
\end{abstract}

Manuscript received on April 20, 2018; accepted

for publication on December 16, 2018

\section{MONIKA INES HAMANN ${ }^{1}$}

https://orcid.org/0000-0001-6999-7417

VIRGINIA LEÓN-RÈGAGNON ${ }^{2,3}$

https://orcid.org/0000-0002-0218-7759

MARÍA VIRGINIA FERNÁNDEZ ${ }^{1}$

https://orcid.org/0000-0001-8657-6323

CYNTHYA ELIZABETH GONZÁLEZ ${ }^{1}$

https://orcid.org/0000-0002-3512-9643 
${ }^{1}$ Consejo Nacional de Investigaciones Científicas y

Técnicas (CONICET), Centro de Ecología Aplicada del

Litoral (CECOAL), W 3400 AMD, Corrientes, Argentina

Estación de Biología Chamela, Sede Colima, Instituto

de Biología, Universidad Nacional Autónoma de

México (UNAM), San Patricio, Jalisco 48980, México

${ }^{3}$ Centre for Biodiversity Genomics, University

of Guelph, Guelph, ON, N1G 2W1, Canada

Correspondence to: Monika Ines Hamann

E-mail:monika_hamann@yahoo.com

\section{Author contributions}

All authors participated in the drafting the article or revising it critically content, approving the final version submitted for publication. MIH, CEG, MVF collected the data, MIH made the figures and led the writing of the manuscript and VLR analyzed the genetic data.

\section{(cc) BY}

